\title{
Web-based recruiting's impact on organizational image and familiarity: Too much of a good thing?
}

Melissa L. Intindola* ${ }^{\mathrm{a} *}$, Gabriella Lewis ${ }^{\mathrm{b}}$, Carol Flinchbaugh ${ }^{\mathrm{b}}$ and Sean E. Rogers $^{\mathrm{c}}$

${ }^{a}$ Department of Management, Haworth College of Business, Western Michigan

University, Kalamazoo, MI, USA ${ }^{b}$ Department of Management, New Mexico State

University, Las Cruces, NM, USA; 'SChool of Hotel Administration, Cornell University,

Ithaca, NY, USA, * corresponding author

Melissa L. Intindola

Department of Management

Haworth College of Business

Western Michigan University

1903 W Michigan Ave

Kalamazoo MI 49008-5429 USA

P: (269) 387-5661

E: melissa.intindola@wmich.edu

Gabriella Lewis

College of Business

Management Department

MSC 3DJ, PO Box 30001

New Mexico State University

Las Cruces, NM 88003-8001

E: glewis08@nmsu.edu

Carol Flinchbaugh

College of Business

Management Department

GU 213, PO Box 30001

New Mexico State University

Las Cruces, NM 88003-8001

P: (575) 646-5764

E: cflinch@nmsu.edu

Sean E. Rogers

School of Hotel Adminstration

Cornell University

565C Statler Hall

Ithaca, NY 14853-6201

P: (607) 255-3847

E: ser265@ cornell.edu 


\section{Web-based recruiting's impact on organizational image and familiarity: Too much of a good thing?}

Little is known about the efficacy of many of the newer forms of online recruitment. Using a quasi-experimental design, we tested the impact of individual exposure to corporate recruitment websites and Facebook on perceptions of organizational familiarity and organizational image over time. Most interestingly, we found evidence of a curvilinear or non-linear relationship between frequency of exposure to organizational communications and perceptions of organizational familiarity across time. Implications of our findings for HR theory and practice are discussed.

Keywords: e-HRM; HR branding; online recruitment; organizational familiarity; organizational image

\section{Introduction}

The war for talent (Aguinis, Gottfredson, \& Joo, 2012; Beechler \& Woodward, 2009; Chambers, Handfield-Jones, \& Michaels, 1998; Michaels, Handfield-Jones, \& Axelrod, 2001) and organizational efforts to gain competitive advantage have created a more strategic approach to human resource (HR) recruiting practices, ultimately giving birth to employer branding. Similar to corporate brand personality, the goal of employer branding is promotion of the company's attributes and values to prospective applicants (Knox \& Freeman, 2006; Lloyd, 2002). More recently, Bondarouk, Ruel, Axinia, and Arama (2014) define employer branding as 'a long-term strategy of any given company, aimed at both building a unique and desirable employer identity and managing the perceptions of prospective and current employees, in order to gain competitive advantage' (p. 27). Essentially, employer branding charges HR personnel with creating 
and signaling company messages in such a way so as to positively influence applicant job choice. Recent research suggests companies who portray a strong 'brand' are more favorably evaluated by potential candidates (Elving, Westhoff, Meeusen, \& Schoonderbeek, 2013).

Complicating efforts to portray a strong brand, recruitment methods have changed in the last decade, and such efforts to affect applicants' perceptions of potential employers have been altered by the prevalence of Internet technology (Bondarouk et al., 2014). Corporations are increasingly using online platforms such as job-boards, corporate recruitment sites, and social media websites in their recruitment practices (Allen, Mahto, \& Otondo, 2007). Deemed 'electronic human resource management' (e-HRM) online recruitment is not only flexible and cheap (Capelli, 2001), but it can be used as part of image management (Girard \& Fallery, 2011). For example, an organization may attempt to portray itself as a fun place to work, an innovative place to work, or a workplace that values diversity through its use of online text and visuals. However, it is unclear whether the ease of use associated with e-HRM methods translates to increased ease of recruitment or enhanced recruiting success (Bondarouk, Harms, \& Lepak, 2017). Indeed, Bondarouk et al. (2014) noted the difficulties companies might face in recruiting employees 'in a world where technological advances and global competition are driving widespread changes in employment patterns' (p. 28) and encouraged researchers to more deeply explore the role of these advances in applicant perceptions. Previous research has taken theoretical direction from critical contact (Behling, Labovitz, \& Gainer, 1968; Claus Wehner, Giardini, \& Kabst, 2012) and signaling (Rynes, Bretz, \& Gerhart, 1991) theories to link recruiting practices with applicant evaluation. Critical contact theory suggests that job seekers rely on the contact points they have with the organization to help them evaluate its desirability as an employer. 
This works in conjunction with signaling theory, which suggests that the organization 'signals' its values and attributes via various platforms to job seekers. Extending these existing relationships, we contend that e-HRM platforms serve as moments of critical contact for job seekers, signaling organizational characteristics to them in situations of information asymmetry via various e-HRM platforms.

In considering the value of contacts, this paper explores the effects of potential applicants' exposure to company information via different e-HRM platforms. Specifically, we set out to investigate how individual perceptions of employer familiarity and organizational image are impacted over time both generally and specifically in response to frequency of exposure to e-HRM recruitment efforts. The study design was comprised of two conditions: one group solely reviewed corporate recruitment websites, while the second viewed the organization's Facebook page in addition to its corporate recruitment website. The conditions were important in identifying potential combinations of different e-HRM strategies, particularly given recent practitioner concerns surrounding the dedication of resources (e.g. time and money) used in maintaining these different e-HRM platforms (e.g. Bondarouk \& Olivas-Lujan, 2013; Breaugh, 2014). Our findings indicate that frequency of exposure had unanticipated relationships with study variables, the implications of which may be interesting for both future research in this area and e-HRM practices.

Our contribution to the e-HRM literature is threefold. First, despite suggestions that researchers begin expanding e-HRM literature to consider the use of Web 2.0 technologies like social networking sites (SNSs) (Martin \& Reddington, 2010; Stone, Deadrick, Lukaszewski, \& Johnson, 2015), to date we know of no study that has tested applicant perceptions using corporate social media. By our doing so, we contribute to eHRM theory building by considering how exposure to SNSs affects important recruiting 
outcomes. Second, we attempt to discern differences across various e-HRM branding platforms. And finally, we employ repeated observations over a three-month period to assess responses to e-recruiting over time. This furthers e-HRM theory building by considering the temporal nature of recruiting, a point made by previous reviews of eHRM literature (Dineen \& Soltis, 2011; Strohmeier, 2007; Uggerslev, Fassina, \& Kraichy, 2012). As will be discussed later, this approach led to an important finding that increased exposure to e-HRM platforms may actually have a curvilinear or non-linear effect on e-recruiting outcomes like familiarity. In addition, we contribute to the use of signaling and critical contact theories in recruitment by investigating the use of SNSs as a contact point and evaluating what recruiting outcomes are successfully 'signaled' to job seekers. This paper is structured as follows: first, we provide an overview of our hypothesized relationships with the study constructs. Next, we describe our research process and the results. In the final section, we discuss the practical implications and limitations of our study.

\section{Literature review and hypotheses}

\section{Critical contact theory}

According to critical contact theory, candidates make decisions about the desirability of a particular employer based on moments of interaction with the organization (Behling et al., 1968). These critical contact points can take many forms, from a meeting with a recruiter in person to the facade of the company's building. In particular, for less experienced applicants these critical contact points may aid in decision-making. In these situations, full information about the organization or the position at hand is limited (Behling et al., 1968; Pounder \& Merrill, 2001). As such, applicants hang onto those critical contact elements as 'signals' from the organization. 
Similarly, signaling theory describes how organizations deliberately communicate information to convey positive organizational characteristics and reduce information asymmetry (Spence, 2002). During the signaling process the sender decides which information is shared and how to communicate (signal) that information. The other party, the receiver, needs to interpret this signal (Connelly, Certo, Ireland, \& Reutzel, 2011). The mutual participation between sender and receiver found in signaling theory makes it uniquely applicable to the recruitment process. Indeed, extant recruitment research has used signaling theory to conceptualize how organizations share job expectations through the recruitment process (Bangerter, Roulin, \& Konig, 2012; Suazo, Martinez, \& Sandoval, 2009) and how applicants draw inferences of organizational characteristics based on peripheral cues (Braddy, Meade, \& Kroustalis, 2006), such as recruiters and recruitment brochures (Rynes \& Miller, 1983; Turban, 2001). Extending these existing relationships, we contend that e-HRM platforms serve as moments of critical contact for job seekers, signaling information regarding the organization's 'brand' to them in situations of information asymmetry.

\section{Branding via e-HRM platforms}

Online recruitment and organizational websites in particular, have become the main sources of familiarity and image in the last decade (Allen et al., 2007). Common features of organizational recruitment websites include mission and value statements, benefit and reward information, employee testimonials, and policies (Cober, Brown, Levy, Cober, \& Keeping, 2003). Organizational websites help form first impressions for applicants (Braddy, Meade, \& Kroustalis, 2008) and the information provided on these websites affects viewers' attitudes towards the organization (Allen et al., 2007). Previous recruitment studies have focused on website aspects, such as usability and 
aesthetics (Cober et al., 2003; Williamson, King, Lepak, \& Sarma, 2010). However, research on website components has now been extended to assess their effects on applicant perceptions of the organization, such as perceived person-job fit (Chen, Lin, \& Chen, 2012; Gregory, Meade, \& Thompson, 2013; Lyons \& Marler, 2011).

While organizations have increasingly used company websites for recruitment purposes over the last two decades (Dineen, Ling, Ash, \& DelVecchio, 2007), a growing number of organizations are combining these with newer forms of digital technologies, such as social media tools, to attract applicants. SNSs like Facebook may offer a number of additional advantages in recruiting. First, interested job seekers 'following' an organization on Facebook are able to automatically see important organizational updates using Facebook's newsfeed function. Second, potential applicants can more easily refer a friend to a particular organization by actively sharing the organization's updates via Facebook. Lastly, an organization's network of potential applicants is increased each time a current 'follower' makes a new 'friend' (Caers \& Castelyns, 2010). For these reasons, organizations not already maintaining a social media presence aimed at recruiting have begun to consider the resources necessary to do so (Bondarouk \& Olivas-Lujan, 2013).

Recruitment is an inherently time-sensitive process (Breaugh, 2008). For example, Allen et al. (2007) point out that early in the recruitment process, characteristics of the organization are conveyed via recruitment sources, with an increased prevalence of Web-based recruiting platforms. However, there is little research to date on how potential job applicants respond to this information at a later date (Dineen, Ash, \& Noe, 2002). In summarizing their findings that job and organization information were related to intentions to pursue employment in early recruitment stages, Allen et al. (2007) suggest that future research consider the effects of information across time. For our 
purposes, exposure was designed into a classroom intervention, thus we were assured that students who completed required assignments were, in fact, receiving exposure to either a company's corporate website or its corporate website and Facebook page. Furthermore, we focused our research at the early stages of the recruitment process, as these encounters are crucial points in the recruitment cycle, as proposed by signaling (Rynes et al., 1991) and critical contact (Behling et al., 1968) theories.

\section{Changes in employer familiarity and image as study outcomes}

In the early stages of the recruitment process, initial information sources will likely include online platforms like organization websites (Allen et al., 2007; Cober et al., 2003). Corporate websites help provide applicants with the ongoing organizational communication necessary to reduce information asymmetry (Park \& Mezias, 2005). More generally, recruitment effectiveness is increased when messages are provided consistently across e-HRM platforms. However, research suggests that not all signals are equally effective in terms of generating perceptions of organizational attractiveness. Lievens and Highhouse (2003) contend that different situations may involve multiple signalers, receivers, and/or signals, and possibly even competing signals. The usefulness of a signal depends on the extent to which the signal corresponds with the signaler's sought attributes as well as the signal's reliability. Thus, we believe that within e-HRM platforms, nuances may exist which favor the use of one over another. For purposes of this study, we are interested in how different platforms (corporate recruitment websites and corporate social media outlets, namely Facebook pages) may affect applicant perceptions associated with employer knowledge.

This study focuses on employer knowledge as a key outcome of recruitment information because ultimately the ability of applicants to reduce the information 
asymmetry associated with a particular organization will affect their decision-making processes (Connelly et al., 2011). Employer knowledge accumulated during the recruitment process is a primary indicator of subsequent success or failure as it impacts organizational attraction. Indeed, studies (e.g. Zottoli \& Wanous, 2001) have shown that the source of initial contact with a potential employee (e.g. newspaper or web) is an important factor in the recruitment process. In this study, we focus on two facets of employer knowledge: employer familiarity (i.e. general awareness) and organization image (i.e. attribution, beliefs) (Aaker, 1996; Keller, 1993).

Both organizational familiarity and organizational image have meaningful implications for the recruitment literature. Employer familiarity measures the level of awareness that a prospective applicant has of an organization (Cable \& Turban, 2003). We argue familiarity was particularly important given our current student sample, as it makes sense that a student would have to be aware of a particular company in order to consider it as a potential employer. Furthermore, increased familiarity with a company has been linked to more favorable perceptions (Barber, 1998; Cable \& Turban, 2001; Collins \& Han, 2004), and subsequent application intention (Collins, 2007). Organizational image is defined as the bundle of associations potential applicants hold in memory regarding an organization (Keller, 1993). Allen et al.'s (2007) study showed that proxies of image including job information (directly) and organizational information (indirectly) are related to intentions to pursue employment. We were interested in exploring the effects of time on these perceptions of familiarity and image, such that:

H1a: As a result of being exposed to either a company's Careers Facebook page and its corporate website or solely the company's corporate website, participants' familiarity with the organization will increase over time. 
H1b: As a result of being exposed to either a company's Careers Facebook page and its corporate website or solely the company's corporate website, participants' positive perceptions of the organization's image will increase over time.

\section{Effects of multiple exposures}

While the previous set of hypotheses more generally extends the recruitment literature by considering the effects of time on familiarity and image across different e-HRM platforms, in this section we seek to further understand the relationship between frequency of exposure to e-HRM platforms and our outcome variables.

In his seminal paper introducing the concept of 'mere exposure' to the psychology literature, Zajonc (1968) suggested that an individual's attitude towards a particular stimulus (person, place, or thing) could be positively skewed with increasing exposure to the stimulus being evaluated. Mere exposure, defined as 'a condition making the stimulus accessible to the individual's perception' (p. 1), only requires that an individual have opportunities to consistently interact with the stimulus. Zajonc (1968) further concluded that the frequency with which these interactions occurred resulted in a more positive attitude towards the stimulus. Moreover, Judd and Brauer (1995) suggest that repeated exposure via communications about or from the stimulus not only results in a more positive attitude, but could also change one's attitude extremity towards a previously negative stimulus.

While most commonly considered in advertising (Brooks \& Highhouse, 2006), a limited number of recruitment-specific findings have explored and found support for this exposure-positivity link. For example, Gatewood, Gowan, and Lautenschlager (1993) 
found strong correlations between students' exposure to a company's advertising, including studying the organization in class, and corporate image. The authors attributed these correlations to Zajonc (1968) 'mere exposure' effect, and suggested that future research consider the strong associations among exposure frequency and recruitment outcomes. As such, we hypothesize the following (please see Figure 1 for a depiction of these hypotheses):

H2a: The number of times an individual is exposed to the company's e-HRM recruitment platforms will moderate the relationship between organizational familiarity over time such that an increased number of exposures will result in more familiarity with the organization.

$\mathrm{H} 2 \mathrm{~b}$ : The number of times an individual is exposed to the company's e-HRM recruitment platforms will moderate the relationship between organizational image over time such that an increased number of exposures will result in more positive perceptions of the organization's image.

\section{Methods}

\section{Sample}

The participants in the study were undergraduates from a large Southwestern U.S. university enrolled in an upper level human resource management course, a required course for all management majors pursuing a human resource management concentration. It is important to note that all of the students in the sample were juniors or seniors, $81 \%$ of which indicated they were going to apply for a new job within their field of study in the coming year. All four sections of the course were included in the study, for a total possible $\mathrm{N}=156$ (Section $1 \mathrm{~N}=31$; Section $2 \mathrm{~N}=45$; Section $3 \mathrm{~N}=$ 
37; Section $4 \mathrm{~N}=43$ ). These sections were selected based on the individual instructor's willingness to participate and to conduct the treatment in his or her course. Of the 105 (response rate: $67 \%$ ) students who participated in the study, 51\% were male, $56 \%$ were Caucasian, $31 \%$ reported an ethnicity different than the provided options, $8 \%$ were African American, 3\% were Native Hawaiian or Other Pacific Islander, and 2\% were American Indiana or Alaska Native. The age frequencies of the students were as follows: $54 \%$ were $18-21$ years old, $31 \%$ were $22-25,5 \%$ were $26-30,5 \%$ were $31-35$, and $5 \%$ were over 35 .

\section{Research design}

The authors carefully considered the specific companies to include in the study. We purposefully did not want to select companies at which students might readily admit they wanted to seek employment (e.g. Google or Apple). Instead, the authors selected companies with documented scandals receiving heightened media attention during the 2010-2013 time period. This follows previous research that used signaling theory to explore the link between organizational scandal and current and prospective employee reaction (e.g. Miceli, Near, Rehg, \& Van Scotter, 2012; Wang, 2013). With a focus on corporate scandals, each research team member independently generated an initial company list via a Google search and then confirmed that the companies under consideration had both a corporate careers web page and a Facebook 'careers' page. Next, researchers selected companies with widely publicized scandals, to increase the likelihood that students would be able to understand the scandal with little to no confusion. Finally, the authors met and selected a random sample of five companies from different industries - one company each from the automotive (General Motors), retail (Wal-Mart), energy (British Petroleum, or BP), savings and loan (Fannie Mae), 
and technology (Hewlett Packard) industries. These same five companies were used in all four treatment sections. Students in each section were randomly assigned to a company.

Two sections of each course were exposed to one of two treatments: Online recruitment activity without Facebook $(\mathrm{n}=44)$ and online recruitment activity with Facebook $(\mathrm{n}=$ 61). Each condition is described in more detail below. All participants completed a preand post-test survey. Pre-tests were administered during the last week in October, with post-testing occurring in early December.

\section{Online recruitment activity without Facebook}

The basic goal of this exercise was to encourage students to familiarize themselves with an organization's recruiting strategies and self-reflect on their preference to become a part of that organization or not, based on the recruiting materials. Specifically, students in this condition were asked to review the online career pages of one of five companies and complete a written analysis based on the following criteria: (1) What type of work does the company do? (2) How well do their established recruiting and selection guidelines conform to EEO guidelines? (3) What is the career path that this company outlines for you? Is it attractive to you? Why or why not? (4) What can you learn about the company's culture? Would you feel comfortable in that culture?

\section{Online recruitment activity with Facebook}

In addition to visiting the company's online career page, students in this condition were also asked to follow the company on Facebook for four weeks following assignment by the instructor. As described above, the authors were interested in how the specific 
inclusion of a social media e-HRM platform may affect students' perceptions of the organization. It is important to note that Facebook was selected as the social media platform due to its ease of access. Students are required to create a LinkedIn account to view employers' recruitment information, whereas each of the companies we selected maintained a public Facebook careers page, allowing even students without a Facebook account to participate.

\section{Potential validity threats}

Given the quasi-experimental design used in this study (Cook \& Campbell, 1976), the authors attempted to mitigate potential threats to validity. First, because it was not feasible to use the same instructor for all four sections, the authors selected instructors who were willing to participate and taught at least two sections of the course. Thus, of the four sections participating in the study, each instructor taught two sections. According to the study design, each instructor taught a section in each study condition. Further, both instructors used similar course materials and possessed similar teaching styles. For example, both instructors emphasized experiential learning, group work, and use of the same textbook. Importantly, both instructors were very familiar with the ideas and goals of the study, and thus understood the importance of introducing and implementing the conditions in a consistent manner.

Relatedly, to minimize any potential threats to validity associated with the instructors also being co-authors (Cook \& Campbell, 1976), a research team member who was not the instructor administered pre- and post-test surveys for all students. Further, both instructors provided extra credit to participants to avoid instructor biases related to student responses. 
Lastly, we sought to mitigate potential validity threats associated with participant selection. In other words, selection bias could exist if there were differences across conditions in the characteristics of our student sample. To mitigate the potential impact of this threat, we chose a course required for all students seeking a human resources management concentration. Post hoc analyses also demonstrated that there were not significant differences between students for age, gender, ethnicity, career status (whether or not students intended to apply for a new job within their fields of study in the coming year or not), or major (although all students were seeking a human resources management concentration, their broader majors varied).

\section{Measures}

The pre- and post-semester surveys included measures of organizational image, employer familiarity, assigned company, and study controls. A sample item is shown for each scale below. All scales were rated on a 7-point Likert scale (1 = Strongly disagree, $7=$ Strongly agree) .

\section{Organizational image}

Five items from Erhart et al.'s (2012) study of web-based recruitment among millennial were used to assess participants' general impression of the organization. A sample item is 'The organization has a positive work environment.' Cronbach's alpha was .90 at Time 1 and .93 at Time 2. 


\section{Employer familiarity}

Employer familiarity was measured through a single item from Baum and Kabst's (2014) study of web versus print recruiting strategies. The item 'I am very familiar with this company as an employer' had a reliability of .92 at Time 1 and 1.00 at Time 2. Reliabilities were calculated using Wanous and Hudy's (2001) correction for attenuation method for assessing single-item reliability. Single-item measures are appropriate in cases where the construct is 'narrow' or 'unambiguous' to the study participants (Sackett \& Larson, 1990).

\section{Frequency of exposure}

Students were asked to report the number of times they reviewed their assigned company's recruitment webpage (all conditions). Students in the Facebook- included condition were also asked to report the number of times they reviewed their assigned company's Facebook careers page.

\section{Controls}

Consistent with previous studies of web-based recruitment (e.g. Ehrhart et al., 2012), we included participant age, work experience, and resistance to persuasion as possible control variables. These variables have also predicted our variables of interest where traditional recruiting platforms were used (e.g. Allen et al., 2007; Lievens \& Highhouse, 2003; Turban, Forret, \& Hendrickson, 1998). To control for potential differences between active and passive job seekers (Collins \& Kanar, 2013), participants reported if they plan to apply for jobs in the upcoming year. Lastly, students' pre-existing company knowledge was included as a control variable to account for prior exposure. 


\section{Results}

Table 1 presents means and standard deviations for each of the relevant variables. Additionally, it presents correlations among the variables of interest and control variables. Study findings indicate that the control variables included were not significant; thus for simplification we report findings without the inclusion of these controls.

\section{Tests of hypotheses}

Ordinary least squares regression was used to test the first set of hypotheses, with posttest perceptions of employer familiarity and organizational image included as dependent variables and our variables of interest as predictors, holding pre-test perceptions constant. For this set of hypotheses, we were interested in the differential effects of various e-HRM platforms, namely the organization's webpage and its Facebook page. Hypothesis 1a was partially supported, as participants' perceptions of organization familiarity positively increased over time when they were also instructed to follow the company on Facebook $(\beta=.19, \mathrm{p}<.05)$ but not when only instructed to visit the company's webpage $(\beta=.15, \mathrm{p}>.05)$. Hypothesis $1 \mathrm{~b}$ was not supported, with no significant positive increases over time for organizational image, regardless of e-HRM recruitment platform $(\beta=-.01, p>.05$ and $\beta=.07, p>.05$ for corporate website and with the inclusion of Facebook, respectively). Tables 2 and 3 presents the results of this analysis.

In accordance with Cohen, Cohen, West, and Aiken (2003) and Wu, Kwan, Wei, and Liu (2013), Hypotheses 2a and 2b were tested using separate hierarchical moderated multiple regression analysis. For example, for Hypothesis 2a employer familiarity at 
Time 2 was entered as the dependent variable, while employer familiarity at Time 1 and Exposure (coded as the number of times students reported viewing the company's eHRM recruitment platforms, regardless of source) were entered as the first independent variables (first block). The second step consisted of entering the two-way interaction (employer familiarity at Time $1 *$ exposure) as an additional independent variable (second block). The most interesting findings were how this quantification affected employer familiarity. The interaction term accounted for significant additional predictive ability in employer familiarity at Time 2 and provides support for Hypothesis $2 \mathrm{a}\left(\beta=-.63, \Delta \mathrm{R}^{\wedge} 2=.04, \Delta \mathrm{F}=4.13, \alpha=.05\right)$. The presence of a negative interaction term suggests that the relationship between familiarity across time is negative in the presence of exposure, such that increased exposure would actually lead to a decrease in familiarity across time. To follow up on this finding, the means of the students' postfamiliarity perceptions were ordered across four groupings of number of views as follows:

Students viewing e-HRM platforms once had the second lowest adjusted mean $(\mathrm{M}=4.14)$, students viewing information 2-5 times had the lowest adjusted mean $(M=4.05)$, students viewing information 6-8 times had the highest adjusted mean $(M=4.83)$, and students viewing information 9 or more times had the second highest adjusted mean $(M=4.50)$. Taken together, these results suggest a unique moderating effect of exposure, such that there may be saturation points wherein too many views have diminishing returns for familiarity. This is a point we return to in the next section. No support was found for the moderating role of frequency of exposure to e-HRM platforms on perceptions of the organization's image over time as expected in Hypothesis $2 \mathrm{~b}$ 
$\left(\beta=-.39, \Delta \mathrm{R}^{\wedge} 2=.06, \Delta \mathrm{F}=.78, \alpha=.05\right)$. Tables 4 and 5 present the results of these analyses.

\section{Discussion}

The primary purpose of this study was to more fully understand how prospective applicants' critical contact with various e-HRM recruitment platforms (e.g. social media pages and corporate website pages) 'signals' perceptions of familiarity and image over time. To date, much of the extant recruitment literature has focused on the value of more static information media, such as career fairs and paper brochures (Rynes \& Miller, 1983; Turban, 2001). More recent literature has begun to examine the effects of digital media, such as organizational webpages (e.g. Allen et al., 2007). However, given the prevalent use of social media tools (e.g. Facebook, LinkedIn) by younger job applicants, this research was motivated by the possibility that a dynamic recruitment presence via newer e-HRM platforms may actually be beneficial in changing applicant's organizational perceptions. We examined the differential outcomes of organizational digital technologies (Facebook and career webpages) on potential applicant perceptions over time. Overall, our results do indicate that, at least in the case of familiarity perceptions, a combination of corporate careers website and Facebook page exposure did account for differences in perception over time. This suggests that perhaps some of the dynamism (i.e. more frequent updates and interactive features) associated with social media websites more easily translates into increased familiarity with a particular organization than does solely viewing a static corporate webpage.

Perhaps our most interesting finding has to do with how frequency of exposure changes participants' perceptions of organizations. In particular, we find that increasing levels of information, as measured by number of web views, increases levels of organizational 
familiarity, albeit in a nonlinear fashion. This suggests that more exposure does not always lead to improvements in organizational perceptions.

\section{Theoretical and practical implications of this research}

Our primary theoretical contribution extends our understanding of the effectiveness of different sources and levels of recruitment-specific information to change personal perceptions of the organization (Allen et al., 2007). Importantly, the study's findings refine current conversations on e-recruiting, which to date have focused on how to provide applicants with information (e.g. discussions of website aesthetics) while neglecting how much information is beneficial. Our initial discovery of a nonlinear relationship across heightened levels of information shows that individual searches for information have the potential to both increase and decrease levels of organizational familiarity, depending on the number of exposures. In addition, we identify how individuals' use of different e-HRM combinations may differentially affect perceptions of familiarity. As such, and extending what we know about signaling theory and critical contact theory, we demonstrate that more critical contact sources (i.e. viewing both Facebook and careers webpages) lead to increased familiarity perceptions. However, the number of critical contacts made with the organization (i.e. exposure) may have various saturation points, such that beyond a certain number of exposures organizational signals actually decrease familiarity perceptions. This counterintuitive relationship is consistent with other recent management attention to 'too much of a good thing' (cf., Karcisky, 2014; Langfred, 2004) effects, and suggests more broadly the need to re-examine our previously held notions of 'more is better.' For example, it has been long proposed in the branding/advertising literature that message repetition has a curvilinear relationship 
with effectiveness (e.g. Berlyne, 1970; Cacioppo \& Petty, 1979; Campbell \& Keller, 2003).

Our research discovery of these saturation points also extends the known limitations of organizational recruitment methods as signals to potential applicants, such as Connelly et al.'s (2011) suggestion that the value of signals may diminish as the number of signals increases and Allen et al.'s (2007) suggestion that recruitment messages may not have the same effects on potential applicants over time. Although this finding may seem counterintuitive, our results indicate that increased levels of recruitment information via both static career webpages and dynamic social media platforms have the potential to both enhance and sap positive organizational perceptions, depending on how frequently a potential applicant solicits information. As such, the findings extend our understanding of the limitations to increased levels of organizational information. Consistent with previous research that reported the effects of information overload on managers (Edmunds \& Morris, 2000), 'star' employees (Oldroyd \& Morris, 2012), and hourly employees (Griffeth, Carson, \& Marin, 1988), we find similar deleterious results of information overload to prospective employees. Future research should examine if information overload is found as applicants view other SNSs, such as LinkedIn.

Although our research was intended to test theoretically driven hypotheses, our findings do have practical implications for HR personnel and job applicants alike. First, supporting what we know about the possibility of inconsistent message signaling across different mediums in the recruitment literature (Highhouse, Thornbury, \& Little, 2007) and the curvilinear effects of message repetition effectiveness (Berlyne, 1970), our inconclusive results suggest that HR managers should further examine the potential differences in applicant's organizational perceptions across different e-HRM platforms. In line with Harold and Ployhart's (2008) recommendation, we also suggest that 
organizations should pay close attention to how the recruitment process and information distribution is designed at various recruitment stages. Our results surrounding differences between information found solely on career webpages as compared to these pages and the inclusion of social media pages indicate that the potential organizational costs - in both personnel time and technology costs - given to social media webpages development and ongoing oversight may in fact be beneficial. However, given that image perceptions were not affected (only familiarity), serious consideration should be given to whether the required resources will lead to desired recruitment gains. In other words, we may expect that following a company on Facebook would naturally increase one's familiarity with the company. A more interesting assertion would have been that following a company on Facebook would have improved potential applicants' image of that company over time, a point we return to later.

Unfortunately for HR personnel, our findings regarding saturation points associated with exposure result in more questions than answers. While our results suggest that the use of Web 2.0 sources in recruitment (i.e. Facebook) match well with pre-existing sources like corporate careers webpages, we understand that HR personnel cannot restrict how often prospective applicants access these various platforms, nor can we provide a 'sweet spot' for personnel in terms of how much information to provide. However, recent work on 'forgetting' may provide important insights. Connerton (2008) identified 'forgetting as annulment' as a natural coping mechanism of individuals in response to 'information overload' (Bawden \& Robinson, 2009; Bondarouk et al., 2014; Bucher, Fieseler, \& Suphan, 2013). The author suggests that knowing information is retrievable, as it would be on an organization's website and/or Facebook page, is tantamount to knowing it is forgettable (Connerton, 2008). This may account for the nonlinear effects of exposure on familiarity - increased exposure levels 
may lead to decreased familiarity perceptions when individuals 'forget' what they have seen, because they know they can see it again. For HR personnel, this suggests a need to focus on dynamic e-HRM platforms with the removal of old content. This does not necessarily mean platforms require daily overhauls; perhaps simple 'daily updates' on the recruitment process or 'daily stories' on what it means to be an employee of an organization would be enough to train individuals to 'remember' an organization, particularly as they came to realize that the organization's e-HRM platforms are everchanging and thus non-retrievable.

One final interesting result deserves attention. Given the lack of support for our organizational image predictions, we postulate post hoc that the differences between the companies involved in the study may have played a role in this outcome. To test this, we analyzed the potential moderating effect of company, and found significant results for its effects on post-test image perceptions $(\mathrm{F}=2.88, \alpha=.03)$. Follow-up testing for mean differences revealed that the pre/post test images of companies ' 1 ' $(\mathrm{GM}, \mathrm{M}=$ $4.88)$ and ' 5 ' (BP, $M=4.96)$ were significantly different from one another $(\alpha=.01)$ and companies ' 1 ' (GM, $\mathrm{M}=4.88)$ and ' 3 ' $(\mathrm{HP}, \mathrm{M}=5.57)$ had marginally significantly different $(\alpha=.11)$ pre/post test images. Taken together, these results suggest that the ability of various e-HRM platforms to affect organizational image may be industrydependent. Future research would benefit from culling samples to include multiple companies in each industry type, and comparing the effects of an intervention like ours on organizational image across each type.

Although the findings of this study are generally supportive of our hypotheses, our research is not without limitations. This study relies on self-report survey responses from a student population. The use of survey responses from two distinct time points were shown to be empirically distinct in our measurement models, mitigating the 
concern that common method bias alone can explain the study's results (Podsakoff, MacKenzie, Lee, \& Podsakoff, 2003). In addition, while $81 \%$ of our sample indicated that they were actively participating in a career search within the next year, the exclusive use of a student sample may not be generalizable to a wide range of job applicants. Future research should examine our findings with applicant samples that are actively applying to desirable organizations and extend our examination beyond Facebook, to assess the value of alternative e-HRM platforms (e.g. LinkedIn) and amount of time applicants use SNSs.

Moreover, future research should move beyond employee perceptions of organizational image and familiarity to include behavioral measures that assess immediate, behavioral responses to one's perceptions. Such behavioral responses may include active application to jobs, emailing the organization for more information, or seeking additional company information via another e-HRM platform.

Finally, future research may consider whether e-HRM platforms are managed in-house or outsourced to a third party, and how these distinctions play a role in the outcomes identified here. This could be an important extension of recent research findings that suggest a heavily outsourced recruitment process may negatively affect company attractiveness (Claus Wehner et al., 2012).

\section{Conclusion}

Our research provides a more complete view of the complex relationship between applicants' perceptions of potential employers and the e-HRM recruitment platforms that are increasingly used to convey employer branding messages (Bondarouk, Ruel, Axinia, \& Arama, 2014). We argued that the inclusion of dynamic e-HRM platforms 
would be influential in changing participants' organizational perceptions. What we discovered was that while Facebook exposure did increase applicants' perceptions of employer familiarity over time more broadly, the amount of organizational information has a unique relationship with employer familiarity. Beyond certain saturation points, 'mere exposure' had the unexpected result of decreasing familiarity with a company. Results of our study extend the use of signaling and critical contact theories to assess effectiveness in changing individuals' perceptions of the organization via different eHRM platforms and with varying information levels. 


\section{References}

Aaker, D. A. (1996). Building strong brands. New York, NY: The Free Press.

Aguinis, H., Gottfredson, R. K., \& Joo, H. (2012). Using performance management to win the talent war. Business Horizons, 55, 609-616.

Allen, D. G., Mahto, R. V., \& Otondo, R. F. (2007). Web-based recruitment: Effects of information, organizational brand, and attitudes toward a Web site on applicant attraction. Journal of Applied Psychology, 92, 1696-1708.

Bangerter, A., Roulin, N., \& Konig, C. J. (2012). Personnel selection as a signaling game. Journal of Applied Psychology, 97, 719-738.

Barber, A. E. (1998). Recruiting employees: Individual and organizational perspectives. Thousand Oaks, CA: Sage.

Baum, M., \& Kabst, R. (2014). The effectiveness of recruitment advertisements and recruitment websites: Indirect and interactive effects on applicant attraction. Human Resource Management, 53, 353-378.

Bawden, D., \& Robinson, L. (2009). The dark side of information: Overload, anxiety and other paradoxes and pathologies. Journal of Information Science, 35, 180191.

Beechler, S., \& Woodward, I. C. (2009). The global "war for talent". Journal of International Management, 15, 273-285.

Behling, O., Labovitz, G., \& Gainer, M. (1968). College recruiting: A theoretical base. Personnel Journal, 47, 13-19.

Berlyne, D. E. (1970). Novelty, complexity, and hedonic value. Perception \& Psychophysics, 8, 279-286. 
Bondarouk, T., Harms, R., \& Lepak, D. (2017). Does e-HRM lead to better HRM service? The International Journal of Human Resource Management, 28, 13321362.

Bondarouk, T., \& Olivas-Lujan, M. R. (Eds.). (2013). Social Media in Human Resources Management (Vol. 12). Bringley: Emerald Group Publishing.

Bondarouk, T., Ruel, H., Axinia, E., \& Arama, R. (2014). What is the future of employer branding through social media? Results of the Delphi study into the perceptions of HR professionals and academics. Advanced Series in Management, 12, 23-57.

Braddy, P. W., Meade, A. W., \& Kroustalis, C. M. (2006). Organizational recruitment website effects on viewers' perceptions of organizational culture. Journal of Business and Psychology, 20, 525-543.

Braddy, P. W., Meade, A. W., \& Kroustalis, C. M. (2008). Online recruiting: The effects of organizational familiarity, website usability, and website attractiveness on viewers' impressions of organizations. Computers in Human Behavior, 24, 2992-3001.

Breaugh, J. (2014). Employee recruitment. In Miller, V.D., \& Gordon, M.E. (Eds.) Meeting the challenges of human resource management: A communications perspective: A communication perspective (pp. 29-39). New York, NY: Routledge.

Breaugh, J. A. (2008). Employee recruitment: Current knowledge and important areas for future research. Human Resource Management Review, 18, 103-118.

Brooks, M. E., \& Highhouse, S. (2006). Familiarity breeds ambivalence. Corporate Reputation Review, 9, 105-113. 
Bucher, E., Fieseler, C., \& Suphan, A. (2013, January). The stress of being socialreassessing the notion of technostress for social media. In Academy of management proceedings (Vol. 2013, p. 13078). Academy of Management.

Cable, D. M., \& Turban, D. B. (2001). Establishing the dimensions, sources and value of job seekers' employer knowledge during recruitment. Research in Personnel and Human Resources Management, 20, 115-163.

Cable, D. M., \& Turban, D. B. (2003). The value of organizational reputation in the recruitment context: A brand-equity perspective. Journal of Applied Social Psychology, 33, 2244-2266.

Cacioppo, J. T., \& Petty, R. E. (1979). Effects of message repetition and position on cognitive response, recall, and persuasion. Journal of Personality and Social Psychology, 37, 97-109.

Caers, R., \& Castelyns, V. (2010). LinkedIn and Facebook in Belgium: The influences and biases of social network sites in recruitment and selection procedures. Social Science Computer Review, 29, 437-448.doi: 0894439310386567

Campbell, M. C., \& Keller, K. L. (2003). Brand familiarity and advertising repetition effects. Journal of Consumer Research, 30, 292-304.

Capelli, P. (2001). Making the most of on-line recruiting. Harvard Business Review, 79, 139-146.

Chambers, E. G., Handfield-Jones, H., \& Michaels, E. G. (1998). The war for talent. The McKinsey Quarterly, 3, 44-57.

Chen, C. C., Lin, M. M., \& Chen, C. M. (2012). Exploring the mechanisms of the relationship between website characteristics and organizational attraction. The International Journal of Human Resource Management, 23, 867-885. 
Claus Wehner, M., Giardini, A., \& Kabst, R. (2012). Graduates' reactions to recruitment process outsourcing: A scenario-based study. Human Resource Management, 51, 601-623.

Cober, R. T., Brown, D. J., Levy, P E., Cober, A. B., \& Keeping, L. M. (2003). Organizational web sites: Web site content and style as determinants of organizational attraction. International Journal of Selection and Assessment, 11, $158-169$.

Cohen, J., Cohen, P, West, S. G., \& Aiken, L. S. (2003). Applied multiple regression/correlation analysis for the behavioral sciences. Mahwah, NJ: Routledge.

Collins, C. J. (2007). The interactive effects of recruitment practices and product awareness on job seekers' employer knowledge and application behaviors. Journal of Applied Psychology, 92, 180-190.

Collins, C. J., \& Han, J. (2004). Exploring applicant pool quantity and quality: The effects of early recruitment practice strategies, corporate advertising, and firm reputation. Personnel Psychology, 57, 685-717.

Collins, C., \& Kanar, A. M. (2013). Employer brand equity and recruitment research. In K. Y. T. Yu, \& D. M. Cable (Eds.), The Oxford handbook of recruitment (pp. 284-297). New York, NY: Oxford University Press.

Connelly, B. L., Certo, S. T., Ireland, R. D., \& Reutzel, C. R. (2011). Signaling theory: A review and assessment. Journal of Management, 37, 39-67.

Connerton, P. (2008). Seven types of forgetting. Memory Studies, 1, 59-71.

Cook, T. D., \& Campbell, D. T. (1976). The design and conduct of quasi-experiments and true experiments in field settings. Handbook of industrial and organizational psychology, 223, 336. 
Dineen, B. R., Ash, S. R., \& Noe, R. A. (2002). A web of applicant attraction: Personorganization fit in the context of Web-based recruitment. Journal of Applied Psychology, 87, 723-734.

Dineen, B. R., Ling, J., Ash, S. R., \& DelVecchio, D. (2007). Aesthetic properties and message customization: Navigating the dark side of web recruitment. Journal of Applied Psychology, 92, 356-372.

Dineen, B. R., \& Soltis, S. M. (2011). Recruitment: A review of research and emerging directions. In S. Zedeck (Ed.), APA handbook of industrial and organizational psychology (Vol. 2, pp. 43-66). Washington, DC: American Psychological Association.

Edmunds, A., \& Morris, A. (2000). The problem of information overload in business organisations: A review of the literature. International Journal of Information Management, 20, 17-28.

Ehrhart, K. H., Mayer, D. M., \& Ziegert, J. C. (2012). Web-based recruitment in the Millennial generation: Work-life balance, website usability, and organizational attraction. European Journal of Work and Organizational Psychology, 21, 850874.

Elving, W. J., Westhoff, J. J., Meeusen, K., \& Schoonderbeek, J. W. (2013). The war for talent: The relevance of employer branding in job advertisements for becoming an employer of choice. Journal of Brand Management, 20, 355-373.

Gatewood, R. D., Gowan, M. A., \& Lautenschlager, G. J. (1993). Corporate image, recruitment image and initial job choice decisions. Academy of Management Journal, 36, 414-427.

Girard, A., \& Fallery, B. (2011). e-Recruitment: From transaction-based practices to relationship- based approaches. Advanced Series in Management, 8, 143-158. 
Gregory, C. K., Meade, A. W., \& Thompson, L. F. (2013). Understanding internet recruitment via signaling theory and the elaboration likelihood model. Computers in Human Behavior, 29, 1949-1959.

Griffeth, R. W., Carson, K. D., \& Marin, D. B. (1988, August). Information overload: A test of an inverted U hypothesis with hourly and salaried employees. In Academy of management proceedings (Vol. 1988, pp. 232-236). Academy of Management.

Harold, C. M., \& Ployhart, R. E. (2008). What do applicants want? Examining changes in attribute judgments over time. Journal of Occupational and Organizational Psychology, 81, 191-218.

Highhouse, S., Thornbury, E. E., \& Little, I. S. (2007). Social-identity functions of attraction to organizations. Organizational Behavior and Human Decision Processes, 103, 134-146.

Judd, C. M., \& Brauer, M. (1995). Repetition and evaluative extremity. Attitude strength: Antecedents and consequences, 4, 43-72.

Karcisky, T. (2014, January). Too much of a good thing? Risk propensity, need for achievement and performance among franchisees. In Academy of Management Proceedings. Academy of Management.

Keller, K. L. (1993). Conceptualizing, measuring, and managing customer-based brand equity. Journal of Marketing, 57(1), 1-22.

Knox, S., \& Freeman, C. (2006). Measuring and managing employer brand image in the service industry. Journal of Marketing Management, 22, 695-716.

Langfred, C. W. (2004). Too much of a good thing? Negative effects of high trust and individual autonomy in self-managing teams. Academy of Management Journal, 47, 385-399. 
Lievens, F., \& Highhouse, S. (2003). The relation of instrumental and symbolic attributes to a company's attractiveness as an employer. Personnel Psychology, $56,75-102$.

Lloyd, S. (2002). Branding from the inside out. Business Review Weekly, 24, 64-66.

Lyons, B. D., \& Marler, J. H. (2011). Got image? Examining organizational image in web recruitment. Journal of Managerial Psychology, 26, 58-76.

Martin, G., \& Reddington, M. (2010). Theorizing the links between e-HR and strategic HRM: A model, case illustration and reflections. The International Journal of Human Resource Management, 21, 1553-1574.

Miceli, M. P., Near, J. P., Rehg, M. T., \& Van Scotter, J. R. (2012). Predicting employee reactions to perceived organizational wrongdoing: Demoralization, justice, proactive personality, and whistle-blowing. Human Relations, 65, 923954.

Michaels, E., Handfield-Jones, H., \& Axelrod, B. (2001). The war for talent. Boston, MA: Harvard Business Press.

Oldroyd, J. B., \& Morris, S. S. (2012). Catching falling stars: A human resource response to social capital's detrimental effect of information overload on star employees. Academy of Management Review, 37, 396-418.

Park, N. K., \& Mezias, J. M. (2005). Before and after the technology sector crash: The effect of environmental munificence on stock market response to alliances of ecommerce firms. Strategic Management Journal, 26, 987-1007.

Podsakoff, P. M., MacKenzie, S. B., Lee, J. Y., \& Podsakoff, N. P. (2003). Common method biases in behavioral research: A critical review of the literature and recommended remedies. Journal of Applied Psychology, 88, 879-903. 
Pounder, D. G., \& Merrill, R. J. (2001). Job desirability of the high school principalship: A job choice theory perspective. Educational Administration Quarterly, 37, 27-57.

Rynes, S. L., Bretz, R. D., \& Gerhart, B. (1991). The importance of recruitment in job choice: A different way of looking. Personnel Psychology, 44, 487-521.

Rynes, S. L., \& Miller, H. E. (1983). Recruiter and job influences on candidates for employment. Journal of Applied Psychology, 68, 147-154.

Sackett, P. R., \& Larson, J. R., Jr. (1990). Research strategies and tactics in industrial and organizational psychology. In M. D. Dunnette \& L. M. Hough (Eds.), Handbook of industrial and organizational psychology (2nd ed., Vol. 1, pp. 419489). Palo Alto, CA: Consulting Psychologists Press.

Spence, M. (2002). Signaling in retrospect and the informational structure of markets. American Economic Review, 92, 434-459.

Stone, D. L., Deadrick, D. L., Lukaszewski, K. M., \& Johnson, R. (2015). The influence of technology on the future of human resource management. Human Resource Management Review, 25, 216-231.

Strohmeier, S. (2007). Research in e-HRM: Review and implications. Human Resource Management Review, 17, 19-37.

Suazo, M. M., Martinez, P G., \& Sandoval, R. (2009). Creating psychological and legal contracts through human resource practices: A signaling theory perspective. Human Resource Management Review, 19, 154-166.

Turban, D. B. (2001). Organizational attractiveness as an employer on college campuses: An examination of the applicant population. Journal of Vocational Behavior, 58, 293-312. 
Turban, D. B., Forret, M. L., \& Hendrickson, C. L. (1998). Applicant attraction to firms: Influences of organization reputation, job and organizational attributes, and recruiter behaviors. Journal of Vocational Behavior, 52, 24-44.

Uggerslev, K. L., Fassina, N. E., \& Kraichy, D. (2012). Recruiting through the stages: A metaanalytic test of predictors of applicant attraction at different stages of the recruiting process. Personnel Psychology, 65, 597-660.

Wang, R. T. (2013). Modeling corporate social performance and job pursuit intention: Mediating mechanisms of corporate reputation and job advancement prospects. Journal of Business Ethics, 117, 569-582.

Wanous, J. P., \& Hudy, M. J. (2001). Single-item reliability: A replication and extension. Organizational Research Methods, 4, 361-375.

Williamson, I. O., King, J. E., Lepak, D., \& Sarma, A. (2010). Firm reputation, recruitment web sites, and attracting applicants. Human Resource Management, 49, 669-687.

Wu, L. Z., Kwan, H. K., Wei, L. Q., \& Liu, J. (2013). Ingratiation in the workplace: The role of subordinate and supervisor political skill. Journal of Management Studies, 50, 991-1017.

Zajonc, R. B. (1968). Attitudinal effects of mere exposure. Journal of Personality and Social Psychology, 9(2, Pt.2), 1-27.

Zottoli, M. A., \& Wanous, J. P. (2001). Recruitment source research: Current status and future directions. Human Resource Management Review, 10, 353-382. 
Table 1. Descriptive statistics and correlations among variables.

\begin{tabular}{|c|c|c|c|c|c|c|c|c|c|c|c|c|c|}
\hline & & Mean & SD & 1 & 2 & 3 & 4 & 5 & 6 & 7 & 8 & 9 & 10 \\
\hline 1. & Age & 1.77 & 1.12 & - & -.023 & -.035 & .186 & .051 & .050 & .056 & .075 & .090 & .09 \\
\hline 2. & WE & 1.06 & .23 & -.023 & - & .093 & .090 & .122 & .029 & -.177 & -.058 & -.105 & -.02 \\
\hline 3. & $\mathrm{RP}$ & 4.24 & .69 & -.035 & .093 & - & $-.201^{\circ}$ & -.006 & .014 & -.023 & -.141 & -.041 & -.03 \\
\hline 4. & JS & 1.19 & .40 & .186 & .090 & $-.201^{\circ}$ & - & .017 & .066 & -.103 & .232 & .060 & -.02 \\
\hline 5. & PECK & 5.64 & 1.74 & .051 & .122 & -.006 & .017 & - & -.159 & -.107 & -.061 & -.020 & .15 \\
\hline 6. & Familiarity $\mathrm{T} 1$ & 2.96 & 1.75 & .050 & .029 & .014 & .066 & -.159 & .92 & $.235^{\circ}$ & .183 & -.009 & -.13 \\
\hline 7. & Familiarity $\mathrm{T} 2$ & 4.28 & 1.78 & .056 & -.177 & -.023 & -.103 & -.107 & $.235^{\circ}$ & 1.00 & .173 & .161 & .12 \\
\hline 8. & Image $\mathrm{T} 1$ & 4.33 & 1.00 & .075 & -.058 & -.141 & $.232^{\circ}$ & -.061 & .183 & .173 & .90 & $573^{* \prime}$ & -.06 \\
\hline 9. & Image T2 & 5.53 & 1.19 & .090 & -.105 & -.041 & .060 & -.020 & -.009 & .161 & $.573^{* *}$ & .93 & -.04 \\
\hline 10. & FoE & 2.59 & .96 & .09 & -.02 & -.03 & -.02 & .15 & -.13 & .12 & -.06 & -.04 & - \\
\hline
\end{tabular}

Notes: $\mathrm{WE}=$ work experience; $\mathrm{RP}=$ resistance to persuasion; JS = job seeker (applying for jobs in the coming year?); PECK = pre-existing company knowledge; FoE = frequency of exposure. Cronbach's alphas for constructed measures are along the diagonal.

Correlations significant at the following levels: $* * \mathrm{p}<.01 ;{ }^{*} \mathrm{p}<.05$. 
Table 2. Differential effect of e-HRM platforms on employer familiarity.

\begin{tabular}{lccc}
\hline & M1 & M2 & M3 \\
\hline $\begin{array}{l}\text { Independent variable } \\
\text { Emp. familiarity T1 }\end{array}$ & $.21^{\circ}$ & $.23^{\circ}$ & $.22^{\circ}$ \\
e-HRM platform 1 & & & .15 \\
$\quad$ Careers webpage & & .16 & $.19^{\circ}$ \\
e-HRM platform 2 & & & .11 \\
$\quad$ Facebook & .05 & .07 & .04 \\
$R^{2}$ & & .03 & 3.72 \\
$\Delta R^{2}$ & 4.57 & 3.63 & $3.68^{\circ}$ \\
$F$ & & 2.61 & \\
$\Delta F$ & & &
\end{tabular}

Notes: Model 1=employer familiarity @ T1; Model 2= corporate careers website;

Model 3 = company Facebook; all coefficients are standardized Betas.

$*$ Significant at $\mathrm{p}<.05$. 
Table 3. Differential effect of e-HRM platforms on organizational image.

\begin{tabular}{lccc}
\hline & M1 & M2 & M3 \\
\hline $\begin{array}{l}\text { Independent variable } \\
\text { Org. Image T1 }\end{array}$ & $.58^{*}$ & $.58^{*}$ & $.58^{* \prime}$ \\
e-HRM platform 1 & & -.01 & -.01 \\
$\quad$ Careers webpage & & & .07 \\
e-HRM platform 2 & & .34 & .34 \\
$\quad$ Facebook & .34 & .00 & .01 \\
$R^{2}$ & & 23.68 & 16.01 \\
$\Delta R^{2}$ & 47.86 & .93 & .38 \\
$F$ & & \\
$\Delta F$
\end{tabular}

Notes: Model 1 = Organizational Image @ T1; Model $2=$ Corporate careers website;

Model 3 = Company Facebook; all coefficients are standardized Betas.

*Significant at $\mathrm{p}<.05 ; * *$ Significant at $\mathrm{p}<.01$. 
Table 4. Moderating effects of exposure in the relationship between employer familiarity at Times 1 and 2.

\begin{tabular}{|c|c|c|}
\hline & $M 1$ & M2 \\
\hline \multicolumn{3}{|l|}{ Independent variable } \\
\hline Emp. familiarity $\mathrm{T} 1$ & $.25^{*}$ & $.79^{*}$ \\
\hline \multicolumn{3}{|l|}{ Moderator } \\
\hline Exposure & .15 & $.49^{*}$ \\
\hline \multicolumn{3}{|l|}{ Two-way interaction } \\
\hline Emp. familiarity $\mathrm{T} 1 \times$ Exposure & & $-.63^{*}$ \\
\hline$R^{2}$ & .08 & .11 \\
\hline$\Delta R^{2}$ & & .04 \\
\hline$F$ & 4.11 & 4.20 \\
\hline$\Delta F$ & & $4.13^{\circ}$ \\
\hline
\end{tabular}

Notes: Model $1=$ Employer Familiarity @ T1, Exposure; Model $2=$ Moderator Term (Hypothesis 2a); all coefficients are standardized Betas.

$*$ Significant at $\mathrm{p}<.05 ; * *$ Significant at $\mathrm{p}<.01$. 
Table 5. Moderating effects of exposure in the relationship between organizational image at Times 1 and 2.

\begin{tabular}{lcc}
\hline & M1 & M2 \\
\hline Independent variable & & \\
$\quad$ Org. image T1 & $.58^{* \prime}$ & $.78^{*}$ \\
Moderator & & .93 \\
$\quad$ Exposure & -.01 & .39 \\
Two-way Interaction & & -34 \\
Org. image T1 x Exposure & .34 & .34 \\
$R^{2}$ & & .01 \\
$\Delta R^{2}$ & 25.22 & 17.04 \\
$F$ & & .78 \\
\hline$F$
\end{tabular}

Notes: model 1 = organizational Image @ T1, Exposure; model $2=$ moderator Term (Hypothesis 2b); all coefficients are standardized Betas.

$*$ Significant at $\mathrm{p}<.05 ; * *$ Significant at $\mathrm{p}<.01$. 